Int. J. Morphol.,

33(1):251-254, 2015

\title{
An Osteometric Evaluation of the Jugular Foramen
}

\author{
Una Evaluación Osteométrica del Foramen Yugular
}

S. Ishwarkumar*; N. Naidoo*; L. Lazarus*; P. Pillay* \& K. S. Satyapal*

ISHWARKUMAR, S.; NAIDOO, N.; LAZARUS, L.; PILLAY, P. \& SATYAPAL, K. S. An osteometric evaluation of the jugular foramen. Int. J. Morphol., 33(1):251-254, 2015.

SUMMARY: The jugular foramina (JF) are bilateral openings situated between the lateral part of the occipital bone and the petrous part of the temporal bones in the human skull. It is a bony canal transmitting neurovascular structures from the posterior cranial fossa through the base of the skull to the carotid space. Since the JF depicts variations in shape, size, height and volume between different racial and gender groups, along with distinctive differences in laterality from its intracranial to extracranial openings, knowledge of the JF may be necessary to understand intracranial pathologies. Therefore, the purpose of this study was to evaluate the morphometric measurements of the jugular foramen. Various morphometric parameters of the JF and its relation to surrounding structures were measured and assessed in 73 dry skull specimens $(n=146)$. Each of the morphometric parameters measured were statistically analyse using SPSS to determine the existence of a possible relationship between the parameters and sex, race, age and laterality. The comparisons of sex and age with the distance between the JF and lateral pterygoid plate and distance between the JF and foramen magnum yielded statistically significant $\mathrm{p}$ values of 0.0049 and 0.036 , respectively. The results of this study correlated with that of previous studies indicating that measurements regarding the JF are greater on the right side. The provision of morphometric data pertaining to the JF and surrounding structures may assist surgeons and clinicians during operative procedures.

KEY WORDS: Jugular foramen; Morphometry; Surrounding structures.

\section{INTRODUCTION}

The jugular foramen (JF) is considered to be the most complex of all cranial nerve foramina due to surgical access, its irregular shape and formation by two bones, the lateral part of the occipital bone and the petrous part of the temporal bone (Idowu, 2004). The JF is divided by two transverse septa of the inner meningeal layer of dura mater into three compartments (Sinnatamby, 2011). The glossopharyngeal nerve and inferior petrosal sinus share the anterior compartment, the vagus nerve and accessory nerve lie within the middle compartment, while the large posterior compartment is occupied by the termination of the sigmoid sinus (Sinnatamby). Radiologists, ENT and Neurosurgeons are fascinated by the JF due to the advances in surgical procedures involving the middle ear and the base of the skull (Standring, 2008). Vijisha et al. (2013) reported that variation in the anatomy of intracranial venous sinuses may be manifested by the relationship of the size and shape of the JF with that of the internal jugular vein and/or the absence or presence of a prominent superior jugular bulb. Knowledge of the JF may be necessary in the treatment of pathologies that are generally known to affect its contents, viz. meningiomas, paraganglionomas, intracranial meningiomas, metastatic lesions, schwanomas and other inflammatory lesions of the inner ear (Khanday et al., 2013; Vijisha et al.). Although the JF presents variation in shape, size, height and volume within the different racial and gender groups, it also varies in laterality from its intracranial to extracranial aspects (Vijisha et al.). Since a review of the literature revealed a lack in the documented JF morphometry, the purpose of this study was to evaluate a combination of reported and unique morphometric parameters of the JF.

\section{MATERIAL AND METHOD}

This study examined 73 dry skull specimens $(n=146)$ obtained from the Department of Clinical Anatomy at the University of KwaZulu-Natal. Healthy skulls that showed no pathological change and damage were included. Skulls that were eroded and deformed were excluded.

\footnotetext{
* Department of Clinical Anatomy, School of Laboratory Medicine and Medical Sciences, College of Health Sciences, University of KwaZulu-Natal, Durban, South Africa.
} 
The measurements of the JF were done directly on each dry skull through the use of a digital calliper (Mitutoyo Digimatic Caliper, Model No. CD-8"C).

\section{Extracranial and intracranial morphometric}

parameters were investigated (Figs. 1 and 2). The morphometric data and demographic factors were analyzed using SPSS software package, version 21.0 (SPSSInc., Chicago, Illinois, USA). A p value of $<0.05$ was considered to be statistically significant.

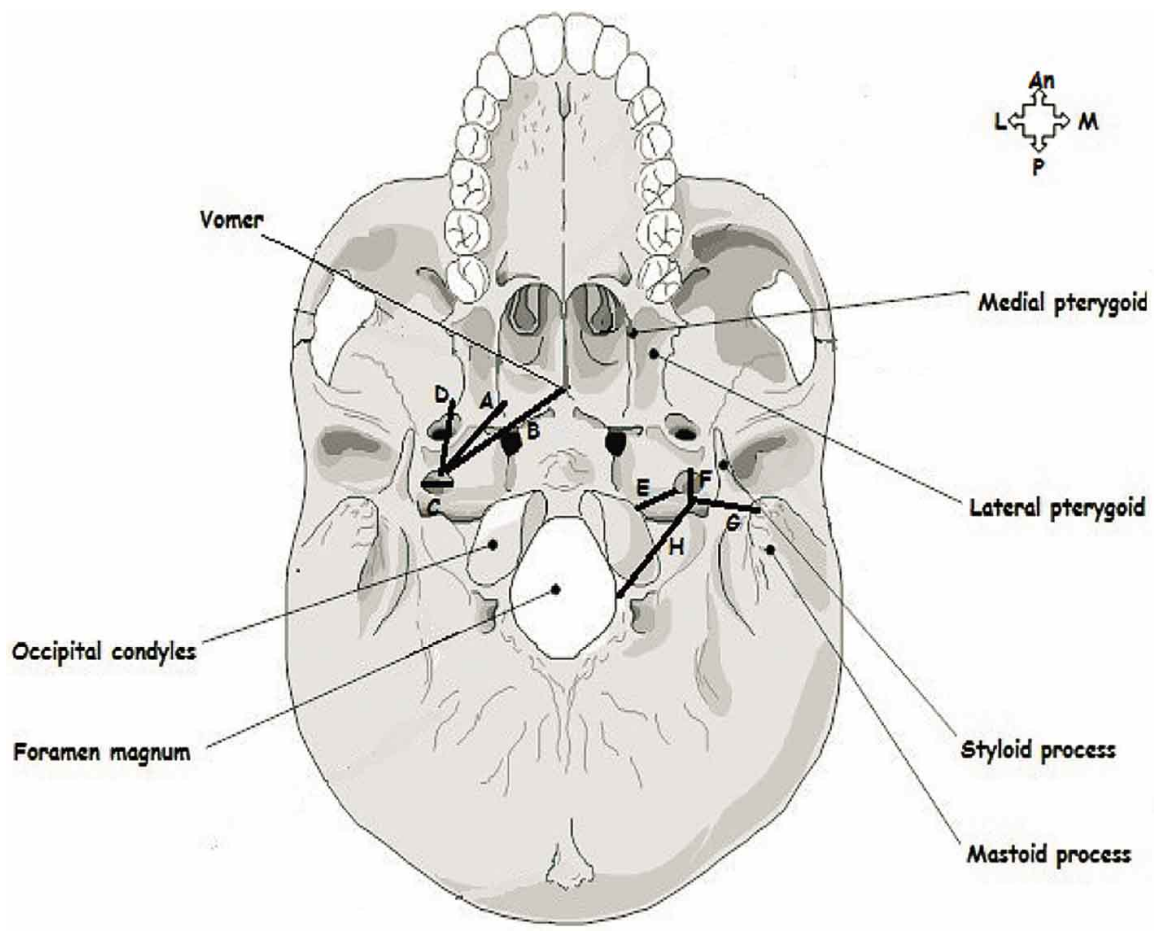

Fig. 1. Inferior view of the extracranial morphometric parameters of the jugular foramen (JF) (Adapted from http:// www.jessicaamato.com/anatomy/ Inferior_View_of_the_Bones_of_the _Skull_Unlabeled_L.jpg

Key: A= Distance between the midline of the inferior border of the medial pterygoid and the anterior border of the JF; $\mathrm{An}=$ Anterior; $\mathrm{B}=$ Distance between the base of the vomer and the anterior border of the JF; C= Width: Transverse/Medio-lateral diameter of the JF from the medial end to the lateral end on the outer and inner surfaces of the skull; $\mathrm{D}=$ Distance between the midline of the inferior border of the lateral pterygoid and the anterior border of the JF; E= Distance between the midline of the occipital condyles and the medial border of the JF; F= Length: Sagittal diameter of the JF from the anterior end to the posterior end on the outer and inner surfaces of the skull; $\mathrm{G}=$ Distance between the apex of the mastoid process and the outer border of the JF; $\mathrm{H}=$ Distance between the midline of the foramen magnum and the inferior border of the JF; L= Lateral; M= Medial; P= Posterior.

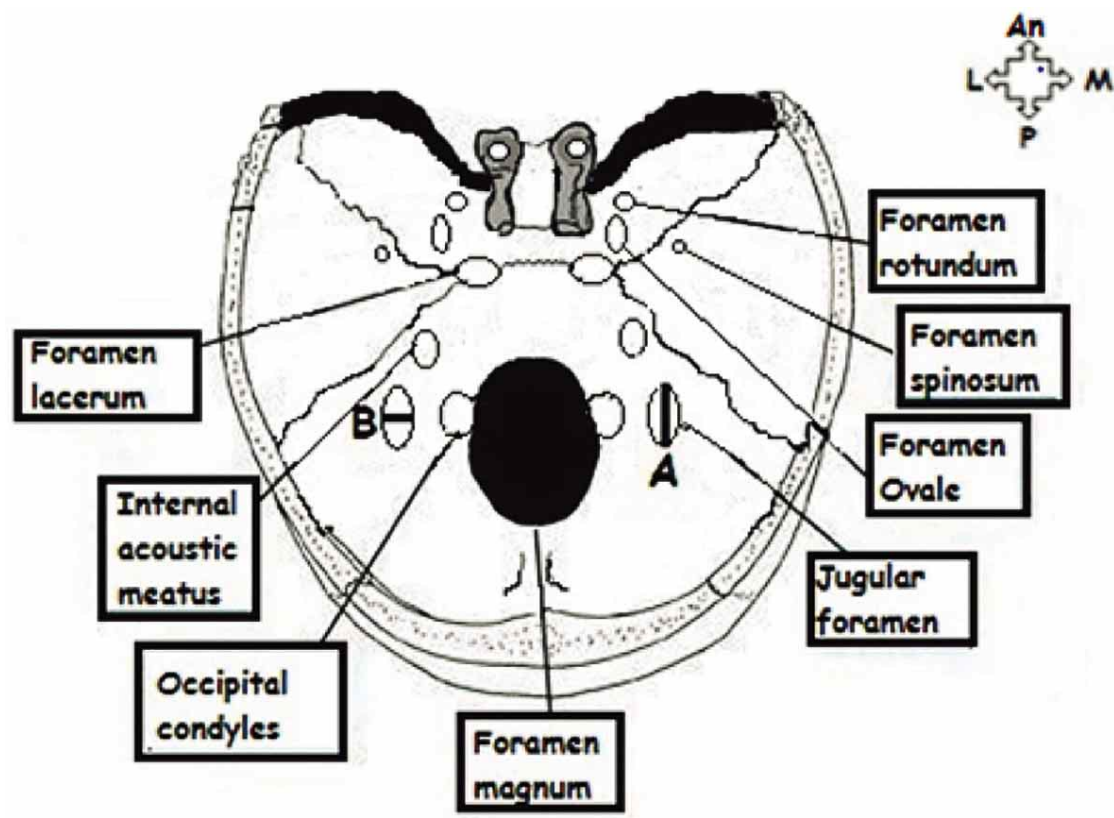

Fig. 2. Superior view of the intracranial morphometric measurements of the jugular foramen (JF) (Adapted from: http:// medchrome.com/basic-science/anatomy/ structures-passing-through-foramina-ofskull/).

Key: A= Length: sagittal diameter of JF from anterior end to posterior end on the outer and inner surfaces of the skull; $A n=$ Anterior; $B=$ Width: transverse diameter of JF from medial end to lateral end on the outer and inner surfaces of the skull; $\mathrm{L}=$ Lateral; $\mathrm{M}=$ Medial; $\mathrm{P}=$ Posterior. 


\section{RESULTS}

The mean intracranial length of the JF was $11.47 \mathrm{~mm}$ and $10.92 \mathrm{~mm}$ on the right and left sides, respectively, while the mean extracranial JF length appeared to be $12.89 \mathrm{~mm}$ on the right side and $12.12 \mathrm{~mm}$ on the left side (Tables I and II). The mean intracranial and extracranial widths of the JF were recorded to be $4.76 \mathrm{~mm}$ and $6.43 \mathrm{~mm}$ on the right side and $4.05 \mathrm{~mm}$ and $5.39 \mathrm{~mm}$ on the left side, respectively (Tables I and II). The mean extracranial distances between the JF and surrounding structures were recorded: i) JF and mastoid process (right: $21.91 \mathrm{~mm}$; left: $21.94 \mathrm{~mm}$ ); ii) JF and foramen magnum (right: $22.21 \mathrm{~mm}$; left: $22.47 \mathrm{~mm}$ ); iii) JF and vomer (right: $34.21 \mathrm{~mm}$; left: $33.68 \mathrm{~mm}$ ); iv) JF and medial pterygoid plate (right: $25.86 \mathrm{~mm}$; left: $24.32 \mathrm{~mm}$ ); v) JF and lateral pterygoid plate (right: $23.97 \mathrm{~mm}$; left: 22.89 $\mathrm{mm}$ ); vi) JF and occipital condyles (right: $4.87 \mathrm{~mm}$; left: $4.96 \mathrm{~mm}$ ) (Table II).

$\mathrm{P}$ values of 0.049 and 0.036 were recorded for the comparisons of sex and age with the distance between the $\mathrm{JF}$ and lateral pterygoid plate, and the distance between the JF and foramen magnum, respectively (Table II).

Table I. Mean intracranial morphometry of the jugular foramen (JF).

\begin{tabular}{cccccccc}
\hline Morphometric & \multicolumn{2}{c}{ Mean } & & \multicolumn{4}{c}{ P-value } \\
\cline { 2 - 3 } \cline { 5 - 7 } Parameter & Right & Left & & Sex & Age & Race & Side \\
\hline Length of JF & 11.47 & 10.92 & & 0.283 & 0.467 & 0.475 & 0.369 \\
Width of JF & 4.76 & 4.05 & & 0.434 & 0.081 & 0.949 & 0.612 \\
\hline
\end{tabular}

Table II. Mean extracranial morphometry of the jugular foramen (JF).

\begin{tabular}{|c|c|c|c|c|c|c|}
\hline \multirow{2}{*}{ Morphometric Parameter } & \multicolumn{2}{|c|}{ Mean } & \multicolumn{4}{|c|}{ P-value } \\
\hline & Right & Left & Sex & Age & Race & Side \\
\hline Length of JF & 12.89 & 12.12 & 0.244 & 0.393 & 0.255 & 0.471 \\
\hline Width of JF & 6.43 & 5.39 & 0.290 & 0.338 & 0.498 & 0.288 \\
\hline Distance between JF \& Mastoid Proc ess & 21.91 & 21.94 & 0.165 & 0.100 & 0.111 & 0.212 \\
\hline Distance between JF \& Foramen Magnum & 22.21 & 22.47 & 0.573 & 0.036 & 0.967 & 0.370 \\
\hline Distance between JF \& Vomer & 34.21 & 33.68 & 0.623 & 0.055 & 0.266 & 0.856 \\
\hline Distance between JF \& Medial Ptery goid & 25.86 & 24.32 & 0.247 & 0.764 & 0.670 & 0.519 \\
\hline Distance between JF \& Lateral Ptery goid & 23.97 & 22.89 & 0.049 & 0.439 & 0.485 & 0.288 \\
\hline Distance between JF \& Occipital Condyles & 4.87 & 4.96 & 0.403 & 0.946 & 0.396 & 0.104 \\
\hline
\end{tabular}

\section{DISCUSSION}

There appears to be a number of pathological issues affecting the JF (Idowu). One such pathology is the glomus jugulare tumor which grows within and around the JF (Sethi et al., 2011). As the internal jugular vein, glossopharyngeal, vagus and spinal accessory nerves pass extracranially through the JF; the presence of the glomus jugulare tumor may compress these neurovascular structures thus leading to a loss of hearing and paralysis of the lower cranial nerves (Sethi et al.).

The intra- and extracranial widths and lengths of the JF which was found to be greater on the right side than the left side, correlated with previous studies (Idowu; Osunwoke et al., 2012) (Tables I and II).

The mean morphometric parameters which appeared to be marginally greater on the left side than the right side were the distances between: the JF and mastoid process, JF and foramen magnum, and the JF and occipital condyles
(Table II). The mean value recorded for the distance between the JF and the mastoid process was similar to that recorded by Cicekibasi et al. (2013) (21.20 mm). In addition, a p value of 0.036 was reflective of a statistically significant relationship between age and the distance between the JF and foramen magnum. During lateral transcondylar surgery, an extensive dissection of the paravertebral muscles and vessels and removal of bony structures, viz. occipital condyle and jugular tubercle, are required (Avci et al., 2011). Therefore, the distance between the JF and occipital condyle may assist the surgeon as such surgical manoeuvres may result in subsequent cranio-cervical instability (Avci et al.).

The mean distances between the JF and the medial and lateral pterygoid plates and the vomer were greater on the right side than the left side. A statistically significant difference between sex and the distance between the JF and the lateral pterygoid plate was recorded $(\mathrm{p}=0.049)$ (Table II). 


\section{CONCLUSION}

This study investigated a number of unique morphometric parameters of the JF. The mean size of the JF was found to be greater on the right side than the left side. Prior knowledge of the anatomical features of the JF may assist surgeons and clinicians during operative procedures.

ISHWARKUMAR, S.; NAIDOO, N; LAZARUS, L.; PILLAY, P. \& SATYAPAL, K. S. Una evaluación osteométrica del foramen yugular. Int. J. Morphol., 33(1):251-254, 2015.

RESUMEN: Los forámenes yugulares (FY) son aberturas bilaterales situadas entre la parte lateral del hueso occipital y la porción petrosa del hueso temporal del cráneo humano. Se trata de un canal óseo que da paso a estructuras neurovasculares de la fosa craneal posterior a través de la base del cráneo hasta el espacio carotídeo. Ya que el FY representa variaciones en la forma, tamaño, altura y volumen entre diferentes grupos raciales y sexo, además de las diferencias distintivas en la lateralidad desde sus aperturas intracraneales a las aperturas extracraneales, se hace necesario su conocimiento con el objetivo de comprender las patologías intracraneales. El propósito de este estudio fue evaluar las mediciones morfométricas del FY. Se midieron y evaluaron muestras de 73 cráneos secos, bilateralmente $(n=146)$. Se estudiaron varios parámetros morfométricos del FY y su relación con las estructuras circundantes. Cada uno de los parámetros morfométricos medidos fue analizado estadísticamente con el programa SPSS para determinar la existencia de una posible relación entre los parámetros y sexo, raza, edad y lateralidad. Las comparaciones de sexo y edad con la distancia entre la placa pterigoidea lateral y el FY, y la distancia entre el FY y el foramen magno, arrojaron valores de $\mathrm{p}$ significativos de 0,0049 y 0,036 , respectivamente. Los resultados de este estudio se correlacionaron con estudios previos que indican que las mediciones relativas al FY son mayores en el lado derecho. El suministro de datos morfométricos relativos al FY y las estructuras circundantes puede ayudar a los cirujanos y clínicos durante los procedimientos quirúrgicos.

PALABRAS CLAVE: Foramen yugular; Morfometría; Estructuras circundantes.

\section{REFERENCES}

Avci, E.; Dagtekin, A.; Ozturk, A. H.; Kara, E.; Ozturk, N. C.; Uluc, K.; Akture, E. \& Baskaya, M. K. Anatomical variations of the foramen magnum, occipital condyle and jugular tubercle. Turk. Neurosurg., 21(2):181-90, 2011.

Cicekcibasi, A. E.; Murshed, K. A.; Ziylan, T.; Seker, M. \& Tuncer, I. A morphometric evaluation of some important bony landmarks on the skull base related to sexes. Turk. J. Med. Sci., 34:37-42, 2004.
Idowu, O. E. The jugular foramen -- a morphometric study. Folia Morphol. (Warsz.), 63(4):419-22, 2004.

Khanday, S.; Subramanian, R. K.; Rajendran, M.; Hassan, A. U. \& Khan, S. H. Morphological and morphometric study of jugular foramen in South Indian population. Int. J. Anat. Res., 1(3):1227, 2013.

Osunwoke, E. A.; Oladipo, G. S.; Gwunireama, I. U. \& Ngaokere, J. O. Morphometric analysis of the foramen magnum and jugular foramen in adult skulls in southern Nigerian population. Am. J. Sci. Ind. Res., 3(6):446-8, 2012.

Sethi, R.; Singh, V. \& Kaul, N.V. Morphological variations of a jugular foramen in North Indian human adult skulls. Indian $J$. Otol., 17(1):14-6, 2011.

Sinnatamby, C. S. Last's Anatomy: Regional and Applied. 12th ed. San Diego, Saunders Elsevier, 2011.

Standring, S. Gray's Anatomy: The Anatomical Basis of Clinical Practice. 40th ed. Londres, Churchill Livinstonr, Elsevier, 2008.

Vijisha, P.; Bilodi, A. K. \& Lokeshmaran. Morphometric study of jugular foramen in Tamil Nadu region. Nat. J. Clin. Anat., 2(2):71-4, 2013.

Correspondence to:

Professor K. S. Satyapal

Department of Clinical Anatomy

School of Laboratory Medicine and Medical Sciences

College of Health Sciences

University of KwaZulu-Natal

Private Bag X54001

Durban

4000

SOUTH AFRICA

Email: satyapalk@ukzn.ac.za

Received: 22-07-2014

Accepted: 02-01-2015 